Kohl: a Journal for Body and Gender Research

Vol. 6, No. 3 (Winter 2020)

\title{
Queer South Asian Diasporic Solidarities and Communities of Care
}

Maya Bhardwaj 
COVID-19's disproportionate entrenchment of racialized capitalist violence, a second wave of uprisings against police brutality and anti-Black violence in the US that has spread internationally, the Tory and Bharatiya Janata Party (BJP) parties' crushing fascist victories, the passage of India's Islamophobic Citizenship Amendment Act and the Trans Bill and ensuing nationwide protests, and more, have created a perfect storm of isolation and overwhelm for many queer people of colour living under late-stage capitalism. But there has also emerged an outpouring of activism in diasporic South Asian space - activism that rejects the status quo, practices solidarity with other marginalized communities, and imagines a transformed world that is birthed not only through militant activism but through community care. As a queer South Asian American activist and researcher myself, currently based in the UK, I have seen a burgeoning of leadership by queer South Asian activists in the UK and US diaspora who hold links to nations across the South Asian subcontinent as well as parts of the Middle East, the Caribbean, and East Asia. These activists are organizing around local and subcontinental issues, as well as showing up in solidarity for loved ones by fighting for Black Lives Matter (BLM), Free Palestine, and more. I argue that this solidarity queers borders, nations, and systems by embracing transnational spaces of struggle and connection; it queers western modes of feminism and of struggle that require our martyrdom for our liberation by imagining a movement held in care. In this piece, drawing on conversations I had during lockdown with fellow queer South Asian activists and friends located in the UK and the US, I argue that diasporic activists are creating new frameworks of queer home (Fortier 2002) that build kinship structures, spaces for healing, and places to sharpening collective struggle that reimagines queer feminist visions for the future.

\section{Queer South Asian Diaspora and Ancestry}

"I have to remember that I exist because my ancestors had the audacity to exist. Remembering my way forward feels integral to being a queer South Asian because we were queer before we were colonized." Thara

While queerness has been documented in many forms throughout the subcontinent, from sexual relations between women in zananas, to orgies carved onto temple walls, to male lovers depicted in Urdu poetry, to robust third-sex "hijra" communities, the combination of British colonialism and the rise of Hindutva have led to silencing of queerness not only in the subcontinent itself but in the diaspora (Vanita 2001). While notable progressions like the passage of Article 377 that decriminalized gay sex in India have added energy to diverse South Asian LGBTQ+ movements, the global South Asian diaspora has often instead solidified insular conservative mores in response to a foreign outside world (Dasgupta et al 2018). Raman (2003) argues that in the South Asian diaspora particularly, the emphasis on diaspora as male seed has resulted in a heteropatriarchal culture that passes lineage through male traditions and can stifle any hint of feminist or queer disruptions. Wilson (2006), Das Gupta (2006), and Maira (2012) explore feminist interventions in these South Asian diasporic spaces in the US and the UK; they argue that young women and queer people create alternate spaces of diasporic home that devise new norms and embrace "unruliness" through nightlife, activism, women and queer community spaces, and arts and culture (Das Gupta 2006). Brah (1996) explores 
these troublings of diasporic norms and creation of new diasporic cultures that reject patriarchal mores as liminal "diaspora space."

Gayatri Gopinath (2005) adds to these creation of alternate diaspora spaces through an articulation of "queer female South Asian diaspora" and "queer South Asian diasporic feminism" that rejects patriarchal lineage structures and heteropatriarchal norms of family. Instead, these South Asians queer a notion of diaspora that ruptures nationalist and "heteronormative and patriarchal structures of kinship" (Gopinath 2005:6). They build a diasporic identity that is hybrid, not only in the mixing between the "colonized" and the "colonizer" but in the relationships that grow between communities in diaspora themselves, and through the process of building home, culture, and politics in exile and resistance (Hall 1994). While hybridity as a theory in diaspora has been critiqued for its emphasis on the influence of whiteness or late-stage capitalist globalization, Gopinath - and I - build on hybridity in terms of creation within and between diasporic communities themselves, the production of Bhabha's third spaces, and in the transformation that these spaces and politics exert in resistance to dominant and homogenizing Western cultures (Hutnyk 2006, Gunaratnam 2014). As Gilroy (1999) expands, and Gopinath builds upon, it is in this interplay between diasporas, and in acts of joy-making and resistance between Black and Brown, that yield rich cultural - and hence political - connection. While Gopinath particularly explores South Asian American and British Asian arts and culture spaces, looking at literary texts, film, and queer nightlife, I draw these explorations to modern practices of queer South Asian feminisms through activism and organizing. Alok Vaid-Menon and Fatima Asghar, two prominent queer diasporic South Asian poets and activists, have referred to this practice as reimagining pathways of ancestry. Vaid-Menon refers to their racial justice work and performance as the process of "decolonizing ancestry" (Sajid 2013) through disrupting gender, and Asghar describes their writing and activism as rediscovering "the ancestors who light your path" (Asghar 2018). These queer South Asian feminisms also queer the notion of ancestry, of bloodline, and bring these alternate modes of kinship and ancestry that inform their organizing.

Har, a trans-femme Sikh Punjabi-American youth organizer and friend, told me that she centres "transgenerational, ancestor worship in my work, and I queer ancestor as anybody who came before me that allowed me to exist and be here today." We spoke during lockdown about practices of resistance, solidarity with BLM, and queer and trans resilience. She described how this led her to draw on a wide range of queer and trans ancestors of colour who vision alternate modes of being. Thara, a queer cis-femme KeraliteAmerican organizer and facilitator whom I quote in the beginning of this section, invoked the guidance of her "ancestors who had the audacity to exist" and who were queer before colonization. It was part of a conversation we had about growing queer South Asian diasporic organizing and activism spaces. The form of decoloniality and ancestry that these two reference through audacious ancestors recalls both Asghar and Menon's poems, and also resonates with Anzaldúa's (1987) notion of nepantla, where she reclaims queer ancestry who lives in the in-between, in the borderlands and the precolonial space, and echoes their existences to resist the fabric of American empire and forced migration. Thara connected this practice to being in her "full agency" when facilitating, by finding a practice of activism and solidarity that both invoked her ancestry and found a way of "forward motion" that was creative and liberatory. 
Amar is a genderfluid British-Indian activist friend from Lesbians and Gays Support the Migrants (LGSM), a queer anti-deportation collective based in London. They similarly used an expansive notion of ancestry in resistance. In describing their queerness and their activism together, they invoked the ritualized and exoticized presence of Khusra or Hijra communities at South Asian community events, locating a notion of their own ancestry that diverged from bloodline. They said, "the kinship systems that we have in South Asia are modeled on heteronormative structures, and our culture is also delineated on heteronormativity, so any queer presence is disruptive" but argued that this disruption was a way to create space for queer feminisms in heteronormative organizing. In these white activist spaces, they "dress as extravagantly as possible; if it's a masculine space l'll pump up, hang on your every word" as a way to disrupt the racialization they experience. Instead, they infuse a queer South Asian femininity and feminism through gender fluidity. LGSM has particularly used these notions of queering space to disrupt deportations on commercial flights by Virgin Airlines and to pressure the Home Office and British Airways to cease deportations and the entrenchment of the UK's hostile environment (LGSM 2020).

Similarly, Nik, a queer trans-femme British-Indian whose family migrated from Uganda, mentioned feeling a "normativeness" in South Asian culture that echoes Brah's (1996) indictments of formations of diaspora space mimicking the heteropatriarchy of the neighborhood. Conversely, when we spoke about her involvement with Misery, a QTPOC healing space that has transitioned online during COVID-19, she described this work as a space that connects her South Asian queer ancestry with modern queer of colour diasporic community and community care. She said, "my South Asian organizing came out through my queerness... But I don't know if we're organizing in a political or activist sense," instead emphasizing alternate notions of creating kinship and "finding intimacy" that led her to queer notions of diaspora and ancestry. These notions of queered ancestry and disruption speak to a practice of queer of colour diasporic feminism that rejects normative performances of activism. Like Muñoz' (1999) queer performances as disidentification, they move through enforced identities to develop a self-created diasporic self and lineage.

\section{Queer Diasporic South Asian Feminisms and Solidarities}

"What queerness has done, and queer South Asian leftists do, is there's a fierce rejection of paternalism and such a huge push to bring in other people and stakeholders, to decentralize leadership...I find there to be more of a camaraderie and intimacy to organizing that is brought by queerness. And I think there is an emphasis on dreaming and visioning, and that is very much a queer feminist thing. Whereas paternalistic organizing treats organizing like it is war. What queerness injects is how this is also a project of conceiving, creating, birthing a new world, and queer people always have had to do that." - Har

When I asked Har about the connection between queerness and her activism, she bluntly described how "queer SAA are overrepresented in organizing spaces and it's brilliant." Here, she intuited that queer South Asians in diaspora are rejected from normative space unless they, as Puar (2006) notes, incorporate into acceptable modes of queerness that conform to the nation-state. This resonates across queer diasporic South Asian activist spaces. Activists see the disproportionate labour that queer femmes take on; following 
the lineage of Audre Lorde and the Combahee River Collective (1983), they organize against the triple jeopardy that queer Black women and their social reproductive labour hold in organizing spaces (Bhattacharya 2017). Queer diasporic South Asians work across issues and spaces, from youth organizing to prison abolition to housing justice to caste abolition to advocacy and healing justice. Some queer South Asians in diaspora make tactical or "strategic" decisions about when to live into queerness as an identity, choosing, as Sasha said, "when and how to show up" in order to disrupt "middle-class formations [that were] utopian bubbles at risk of getting crushed."

Building or finding spaces where queer diasporic South Asian feminisms can grow can, as Har notes in the quote beginning this section, disrupt traditional modalities of organizing as war and instead allow space for Lorde's joy and erotic as power. Here, birthing, creating, and visioning are just as critical to the process of organizing as tearing down; as Lorde describes, this ushers in a world of pleasure rather than purely a world of pain. The latter would replace but mimic the status quo. Instead, queer feminist practices of organizing hold space for softness and beginnings in the world-making that activists do. Priyanka, a housing justice organizer and friend who connects her queer lineage to India, the US, and Hong Kong, spoke to me over videocall during lockdown about her practice of activism. She noted that "queerness is about everything, from the way we communicate to accountability processes to how we deal with violence and harm to the political project that we commit ourselves to." For her, queerness was about "redefining or breaking boundaries...and it's important for me to be in a movement space to feel like I can do that, and I can be queer, test boundaries, break systems down and vision and dream."

These projects of testing, redefining, visioning, and dreaming necessitate collaborations with other marginalized communities. They lend themselves to solidarity with a queer Black liberation movement that is unapologetically queer and femme in the way that the founders of Black Lives Matter describe it (Garza 2014). Reaching back to the Combahee River Collective (1983) manifesto, this movement locates triple jeopardy in the oppressions and structures that prevent liberation (Kelley 2019). These ideas of interlinked oppressions - and dreams that rupture these links and usher new futures together - are echoed in Gopinath's (2018) exploration of queer visioning and dreaming as central to queer diaspora. Here, queers of colour from across the world engage in a collective process of "unruly visions" that reshape Brah's diaspora space into a queer iteration of liberation. In the project Vichitra (2020), artist Shayok Misha Chowdhury traces the literal recorded recounting of dreams by queer diasporic South Asians. The surrealist narrative he creates recalls the works of Moraga and Anzaldúa in This Bridge Called My Back (new edition 2015), where queers of colour narrate their lives in a queer space that activates resistance. Cohen (1997) echoes this activation of resistance in their seminal work on radical queer politics, where queers of colour disrupt notions of queer normativity into alternate formations like punk and bulldagger. These queer South Asian organizers describe finding a queer politic from the margins that provides, as Har said, an "outlet, a necessity, a community" to reconcile with normative diaspora space. This notion of queer feminisms resonated for Nik as an embodiment of "kink" where activists were "kinky" people, part of a culture of rupture that was antithetical to "people in suits working for capitalism." Queer of colour kink thus builds a practice and a politic that disrupts dominant power dynamics by interweaving consent through pain. It finds freedom and release in intense connection despite the disconnection of diaspora under white supremacy. And it rejects capitalist modes of 
heteronormative consumption and reproduction by embracing alternate fantasies and families. Queer South Asian diasporic feminisms and kink, thus, disrupt capitalism and instead re-envision queer liberation (Muñoz 2009).

Queerness, queer anti-normativity, and queer South Asian feminisms, push queer South Asians out of Puar's homonationalism. Queer diasporic South Asian identities reject the minority myth's notion of South Asian assimilation into racial capitalism that extracts labour and capital on the backs of people of colour, and particularly Black people (Robinson 2000). This pushing out of normativity also grows solidarities between queer South Asians in diaspora and other queer people of colour through recognizing shared desires for liberation and articulations of world-making that Kelley (2019) explores in Black and Palestinian solidarities. QSANN, the Queer South Asian National Network, has a piece on talking to South Asian elders about BLM that has dominated the internet space of South Asian groups in 2020 (Rathi 2020). Sharmin, a queer Bangladeshi-American organizer, noted "authentic relationships" that grew between Dalit and Black feminists through projects like Say Her Name. Queer diasporic South Asian politics resonates with queer Black feminisms, particularly from a caste and class-oppressed perspective (Soundarajan 2020). Mameni (2018) and Spira (2014) view queerness and queer feminism as a space that echoes Mohanty's (2003) transnational feminisms through anti-normativity and enhancing intimacy through organizing. Queer South Asian feminisms then grow these intimacies by pushing diasporic South Asians out of the normative space, away from aspirational whiteness formed by the model minority myth, and into solidarity with Black liberation, Palestinian liberation, and the liberation of all people. This politics and solidarity recognize the unique perspectives that caste-oppression and Islamophobia usher forth, disrupting the status quo.

\section{Queer Healing and Home}

In many modern iterations of queer diasporic South Asian activism, the practices of building home and healing create new kinship structures and connections. They hold space for overcoming trauma in the ways that Cohen and Muñoz articulate in other diasporic communities of colour. When describing the work she does with Misery, Nik told me:

I thought the work I wanted to do was very frontline, [like] black bloc [anarchist and antifascist] work [or] police justice, but where l'm at and my mental health, it's too triggering and traumatic. So then, am I not revolutionary? But finding care work, meeting Leah Lakshmi, Mia Mingus, I think it's maybe romanticized that trans is revolutionary, but living in a world that wants you dead and supporting that survival is a radical act.

Queer South Asian disability justice activists like Leah Lakshmi Piepzna-Samarasinha serve as alternate community leaders and chosen family, and the act of survival and caring for queer and trans community is a necessary counterpart to the organizing that queer British South Asians do. The community of care itself also straddles lines of solidarity; Nik added that "we created Misery and then 3 other QTPOC mental health things 
have popped up this year, and that's great." Self-propagation is itself a queer act of solidarity and resilience practiced in Black and Brown feminist spaces across the diaspora (Lorde 1981, Cohen 1997).

Finding spaces for care also involves building queer homes founded off of relationship and solidarity: Preet, a member of SouthAsians4BlackLives, told me that "in queer spaces, all we have is each other." As Gopinath describes, queer South Asians experience dislocation from heteronormative diasporic community; hence, Preet found that "queer spaces modeled for me what solidarity looks like and what showing up for others looks like. At its core, the work that we're doing is relationship building." Similarly, Amar told me about "lost [familial and community] support networks" and the resulting "construction of found families" where "we have to care for one another as a point of principle." For Amar, and for many of the queer diasporic South Asians leading activism and solidarity work, "that's what we think of as activism, really." The act of creating queer home is an act of politics as Fortier (2002) and Gopinath (2005) describe. It is one that replaces the bonds lost to heteronormative traditional South Asian spaces and also provides healing for the trauma created by daily queer resilience.

Instead, queer South Asians find care alongside activism in constructed spaces of intimacy. To exist as queer in diaspora is to devise new feminisms that allow us to exist. To be queer and South Asian in the diaspora, to practice activism and solidarity, is to build home together and reimagine what queer home can be, to envision a new world by embracing radical acts of care, belonging, and liberation. 


\section{References}

Anzaldúa, G., 1999. Borderlands / La Frontera: The New Mestiza. Aunt Lute Books.

Asghar, F., 2018. If They Come for Us. Hachette UK.

Chowdhury, S.M., 2020. Vichitra. Dixon Place.

Combahee River Collective, 1983. The Combahee River Collective Statement. Home Girls: A Black Feminist Anthology. Kitchen Table: Women of Color Press, pp. 264-74.

Das Gupta, M. 2006. Unruly Immigrants: Rights, Activism, and Transnational South Asian Politics in the United States. Durham, N.C.: Duke University Press.

Dasgupta, R.K., Gupta, S., and Rao, R., 2018. Global Day of Rage in London: Reflecting on Queer Activisms, New Media and Friendship. In: Banerjea, Niharika and Dasgupta, Debanuj and Dasgupta, Rohit K. and Grant, Jaime M., (eds.), Friendship as Social Justice Activism: Critical Solidarities in a Global Perspective. Kolkata: Seagull Books.

Fortier, A.M., 2002. Queer Diaspora. Handbook of Lesbian and Gay Studies. Sage, pp. 183-197.

Fortier, A.M., 2001. "Coming home:" Queer Migrations and Multiple Evocations of Home. European Journal of Cultural Studies, 4(4), pp. 405-424.

Garza, A., 2014. A Herstory of the \#BlackLivesMatter Movement by Alicia Garza. The Feminist Wire, 7 October. https://thefeministwire.com/2014/10/blacklivesmatter-2/

Gopinath, G., 2005. Impossible Desires: Queer Diasporas and South Asian Public Cultures. Duke University Press.

Gopinath, G., 2018. Unruly Visions: The Aesthetic Practices of Queer Diaspora. Duke University Press.

Gunaratnam, Y., 2014. Rethinking Hybridity: Interrogating Mixedness. Subjectivity, 7, pp. 1-17.

Hutnyk, J., 2005. Hybridity. Ethnic and Racial Studies, 28(1), pp. 79-102.

Kelley, R.D., 2019. From the River to the Sea to Every Mountain Top: Solidarity as Worldmaking. Journal of Palestine Studies, 48(4), pp.69-91.

LGSMigrants, 2020. Queer solidarity smashes borders: a history of LGBT+ solidarity activism. ERA Magazine, 21 July. era-magazine.com/2020/07/21/queer-solidarity-smashes-borders-a-history-oflgbt-solidarity-activism/.

Lorde, A., 1984. Sister Outsider: Essays and Speeches. Crossing Press.

Mameni, S., 2018. What are the Iranians wishing for? Queer transnational solidarity in revolutionary Iran. Signs: Journal of Women in Culture and Society, 43(4), pp. 955-978.

Moraga, C. and Anzaldúa, G. eds., 2015. This Bridge Called My Back: Writings by Radical Women of Color. SUNY Press.

Muñoz, J.E., 1999. Disidentifications: Queers of Color and the Performance of Politics (Vol. 2). U of Minnesota Press.

Muñoz, J.E., 2009. Cruising Utopia: The then and There of Queer Futurity. NYU Press.

Puar, J., 2006. Mapping US Homonormativities. Gender, Place \& Culture, 13(1), pp. 67-88.

Puar, J., 2008. Terrorist Assemblages: Homonationalism in Queer times. Durham, NC: Duke UP.

Rathi, N., 2020. Black Lives Matter: South Asian Americans come to terms with own anti-blackness. Indian Express, 18 June. https://indianexpress.com/article/world/black-lives-matter-south-asianamericans-come-to-terms-with-own-anti-blackness-6465153/ 
Kohl 6.3

336 Robinson, C.J., 2000. Black Marxism: The making of the Black radical tradition. Univ of North Carolina Press. Sajid, Q., 2013. Archiving Feelings, Actualizing the Revolution. SAADA, 5 March. https://www.saada.org/tides/article/alok-vaid-menon

Soundarajan, T., 2020. South Asians for Black Lives: A Call for Action, Accountability, and Introspection.

Wear Your Voice Mag, 3 June. https://wearyourvoicemag.com/south-asians-for-black-lives-a-callfor-action/

Spira, T., 2014. Intimate Internationalisms: 1970s "Third World" Queer Feminist Solidarity with Chile. Feminist Theory, 15(2), pp. 119-140.

Vanita, R. ed., 2013. Queering India: Same-Sex Love and Eroticism in Indian Culture and Society. Routledge. 